\title{
Finite difference simulation of biological chromium (VI) reduction in aquifer media columns
}

\author{
Phalazane J Mtimunye ${ }^{1 *}$ and Evans MN Chirwa ${ }^{1}$ \\ 'Water Utilisation Division, Department of Chemical Engineering, University of Pretoria, Pretoria 0002, South Africa
}

\begin{abstract}
A mechanistic mathematical model was developed that successfully traced the $\mathrm{Cr}(\mathrm{VI})$ concentration profiles inside porous aquifer media columns. The model was thereafter used to calculate $\mathrm{Cr}(\mathrm{VI})$ removal rate for a range of $\mathrm{Cr}(\mathrm{VI})$ loadings. Internal concentration profiles were modelled against data collected from intermediate sample ports along the length of the test columns. For the first time, the performance of a simulated barrier was evaluated internally in porous media using a finite difference approach. Parameters in the model were optimised at transient-state and under near steady-state conditions with respect to biomass and effluent $\mathrm{Cr}(\mathrm{VI})$ concentration respectively. The best fitting model from this study followed non-competitive inhibition kinetics for $\mathrm{Cr}(\mathrm{VI})$ removal with the best fitting steady-state parameters: $\mathrm{Cr}(\mathrm{VI})$ reduction rate coefficient, $k=5.2 \times 10^{-8} \ell \cdot \mathrm{mg}^{-1} \cdot \mathrm{h}^{-1} ; \mathrm{Cr}(\mathrm{VI})$ threshold inhibition concentration, $C_{r}=50 \mathrm{mg} \cdot \ell^{-1}$; and a semi-empirical reaction order, $n=2$. The model results showed that post-barrier infusion of biomass into the clean aquifer downstream of the barrier could be limited by depletion of the substrates within the barrier. The model when fully developed will be used in desktop evaluation of proposed in situ biological barrier systems before implementation in actual aquifer systems.
\end{abstract}

Keywords: in situ bioremediation, porous media reactors, $\mathrm{Cr}(\mathrm{VI})$ reduction, finite difference model

\section{NOMENCLATURE}

$C \quad \mathrm{Cr}(\mathrm{VI})$ concentration $\left(M L^{-3}\right)$

C. $\mathrm{Cr}(\mathrm{VI})$ toxicity threshold coefficient $\left(M L^{-3}\right)$

$F_{c}$ molar flow rate of $\mathrm{Cr}(\mathrm{VI})\left(M T^{1}\right)$

$k$ reaction rate coefficient $\left(L^{3} M^{-1} T^{-1}\right)$

$Q$ inflow rate $\left(L^{3} T^{l}\right)$

$\Delta_{c}$ rate of change of $\mathrm{Cr}(\mathrm{VI})\left(M L^{-3} T^{-1}\right)$

$W$ mass of the aquifer soil particles $(M)$

$\rho$ density of aquifer soil particles $\left(M L^{-3}\right)$

\section{INTRODUCTION}

Industrial activities such as leather tanning, electroplating, wood preservation/processing, and alloy preparation have led to widespread chromium contamination of soils and groundwater resources around the world (Allen et al., 1998; Shi et al., 2009). The improper disposal of $\mathrm{Cr}(\mathrm{VI})$-containing waste from these industries and its subsequent mobility in groundwater aquifers is a subject of paramount concern (Chirwa and Molokwane, 2011; Blowes, 2002). Aquifer systems below and around industrial and mining sites are especially vulnerable to contamination. Contamination of aquifers has resulted in elevated $\mathrm{Cr}(\mathrm{VI})$ levels, sometimes rendering the groundwater unsuitable as a potable water supply source (Egwuonwu et al., 2011; DWAF, 2005; Francisco et al., 2002).

$\mathrm{Cr}(\mathrm{VI})$ has been classified by the USEPA since 1978 as a Class A human carcinogen based on its acute toxicity at high concentration and chronic and subchronic toxicity under

\footnotetext{
To whom all correspondence should be addressed.

욜 +27 (12) 420-5894; fax: +27 (12) 362-5089;

e-mail: mtimunyepi@gmail.com

Received 8 May 2013; accepted in revised form 3 March 2014.
}

low exposure conditions (Federal Register, 2004). Deleterious effects resulting from exposure to $\mathrm{Cr}(\mathrm{VI})$ include skin dermatitis, irritation of the mucous membrane, and DNA damage or mutations (Cheung and Gu, 2007; Caglieri et al., 2006). Cr(VI) has also been known to hinder seed germination and cause morphological changes in plants (James et al., 1984; Towill, 1978). So far, contamination of groundwater resources around mining areas has been shown to exceed the internationally acceptable exposure limit of $0.05 \mathrm{mg} \cdot \ell^{-1}$ in a significant number of groundwater resources (Molokwane et al., 2008; Kobya, 2004; Baral and Engelken, 2002).

Reduction of $\mathrm{Cr}(\mathrm{VI})$ to $\mathrm{C}(\mathrm{III})$ is favoured since $\mathrm{Cr}(\mathrm{III})$ is 1000 times less toxic and more stable than $\mathrm{Cr}(\mathrm{VI})$ in aquatic environments under natural conditions $\left(\mathrm{pH} 7,15-25^{\circ} \mathrm{C}\right.$ temperature) (Boni and Sbaffoni, 2009). Currently, Cr(VI) contamination in groundwater systems is conventionally treated using the pump-and-treat method which involves the extraction of contaminated water from the aquifer, treatment above ground, and injection of the treated water back into the aquifer (Kurniawan et al., 2006; Watts, 1998). Experience at sites where pump-andtreat remediation of Cr-contaminated groundwater is underway suggests that, although it is feasible to remove high levels of $\mathrm{Cr}$ from the subsurface, it becomes more difficult to remove the remaining $\mathrm{Cr}$ as concentration decreases (Wittbrodt and Palmer, 1992). Additionally, the method is environmental intrusive in that chemical agents used in the reduction process and hydroxide precipitates of reduced chromium produce toxic sludge that may be difficult to remediate (Gonzalez et al., 2003; Blowes, 2002).

Recent studies have shown the possibility of using locally isolated organisms to treat $\mathrm{Cr}(\mathrm{VI})$ contaminated groundwater and/or soil. The treatment can be implemented ex situ utilising a pump-and-treat approach or in situ as a permeable reactive barrier (Molokwane and Chirwa, 2009; Tseng and Bielefeldt, 2002; Turick et al., 1998). In the study by Molokwane and co-workers $(2008,2009)$, microorganisms isolated from dried digested sludge (from sand drying beds) successfully reduced 


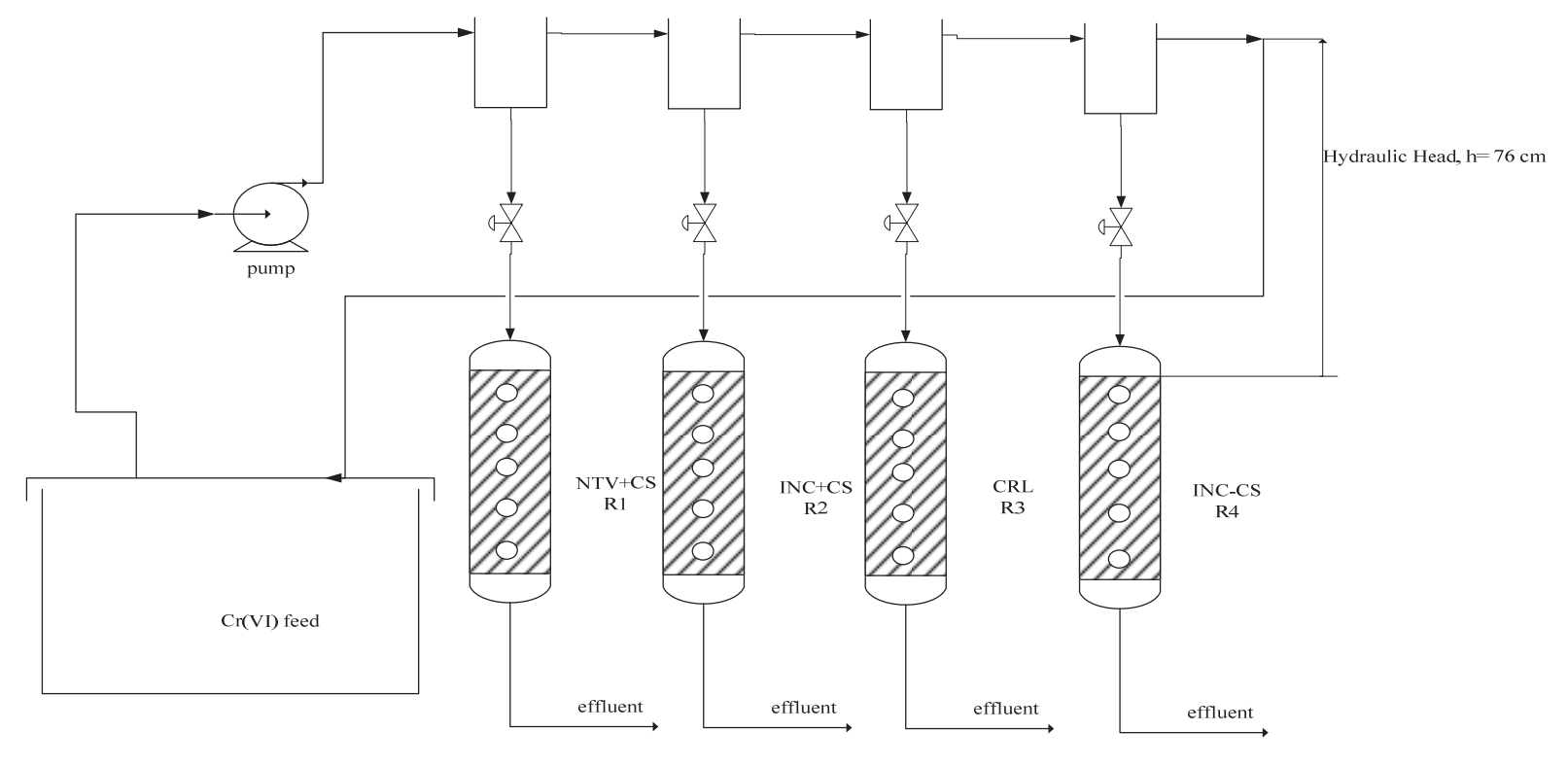

Figure 1

Laboratory set up microcosm columns, where NTV+CS represents the column with native soil bacteria amended with carbon source (sawdust); INC+CS represent column inoculated with a mixed-culture of bacteria and amended with sawdust; CRL represents the sterile (heat-killed cells) column; and INC-CS represents the column inoculated with a mixed-culture of bacteria and without sawdust.

and immobilised $\mathrm{Cr}(\mathrm{VI})$ in extracted aquifer columns in the absence of any added external carbon sources. This demonstrated that a remediation strategy could be implemented using microorganisms without the risk of contaminating the aquifers with external carbon sources and nutrients. The study also demonstrated that locally isolated microorganisms could be adapted to operate at higher $\mathrm{Cr}(\mathrm{VI})$ loading conditions thereby eliminating the need for using foreign isolates of bacteria. However, in spite of these new findings, the activity of the organisms inside the columns was not evaluated.

In this study, the model of $\mathrm{Cr}(\mathrm{VI})$ removal along the reactor columns is evaluated in detail using intermediate sampling ports installed along the reactor columns. This enabled us to plot the $\mathrm{Cr}(\mathrm{VI})$ concentration profiles along the length of the reactor at any given time. The simulation of internal concentration profiles enabled us to evaluate the fundamental physical processes within the soil columns. Without the internal analysis, only a black-box approach may be employed allowing prediction only in a narrow range of operating conditions (Zabiri and Mazuki, 2010; Gomm et al., 1996).

\section{MATERIALS AND METHODS}

\section{Culture and media}

$\mathrm{Cr}(\mathrm{VI})$ reducing organisms were collected from sand drying beds of sludge digester effluent at Brits Wastewater Treatment Works (Brits, North West Province, South Africa). The wastewater treatment plant has received periodic loadings of $\mathrm{Cr}(\mathrm{VI})$ contaminated effluent since 1996, thus some of the microorganisms in the sludge were expected to be $\mathrm{Cr}(\mathrm{VI})$ tolerant and candidates for $\mathrm{Cr}(\mathrm{VI})$ reduction. Isolates capable of reducing $\mathrm{Cr}(\mathrm{VI})$ were purified and sub-cultured under micro-aerobic conditions. All the culturable $\mathrm{Cr}(\mathrm{VI})$-reducing species from the original sludge samples were represented as shown in Table 1.

Bacteria was sub-cultured directly from single species culture slants into sterile Luria-Bettani or nutrient broth amended with $75 \mathrm{mg} \cdot \ell^{-1} \mathrm{Cr}(\mathrm{VI})$ and then incubated at $30 \pm 2^{\circ} \mathrm{C}$

\begin{tabular}{|l|l|c|}
\hline \multicolumn{3}{|c|}{$\begin{array}{l}\text { TABLE 1 } \\
\text { Characterisation of purified cultures grown under } \\
\text { micro-aerobic conditions (Molokwane et al., 2008) }\end{array}$} \\
\hline $\begin{array}{l}\text { Pure } \\
\text { culture }\end{array}$ & Species identified & $\begin{array}{c}\text { \% } \\
\text { Identity }\end{array}$ \\
\hline X1 & $\begin{array}{l}\text { Bacillus cereus strain 213 16S, Bacillus } \\
\text { thuringiensis 16S }\end{array}$ & 99 \\
\hline X2 & $\begin{array}{l}\text { Bacillus sp. ZZ2 16S, Bacillus cereus ATCC } \\
\text { 10987, Bacillus thuringiensis strain Al } \\
\text { Hakam }\end{array}$ & 99 \\
\hline X3 & Bacillus sp. 32-661 16S, Bacillus cereus 16S & 99 \\
\hline X4 & $\begin{array}{l}\text { Bacillus mycoides strain BGSC 6A13 16S, } \\
\text { Bacillus thuringiensis serovar Finitimus } \\
\text { strain BGSC 4B2 16S }\end{array}$ & 99 \\
\hline X5 & $\begin{array}{l}\text { Bacillus mycoides strain BGSC 6A13 16S, } \\
\text { Bacillus thuringiensis serovar Finitimus } \\
\text { strain BGSC 4B2 16S }\end{array}$ & 99 \\
\hline X6 & $\begin{array}{l}\text { Bacillus mycoides strain BGSC 6A13 16S, } \\
\text { Bacillus thuringiensis serovar Finitimus } \\
\text { strain BGSC 4B2 16S }\end{array}$ & 99 \\
\hline X7 & $\begin{array}{l}\text { Microbacterium sp. S15-M4, } \\
\text { Micribacterium foliorum }\end{array}$ \\
\hline
\end{tabular}

for approximately $24 \mathrm{~h}$. The overnight-grown mixed culture of bacteria was then harvested by centrifugation and washed twice with $0.85 \%$ sterile $\mathrm{NaCl}$. Finally, the cells were suspended in sterilised modified basal mineral medium (BMM) prepared according to Roslev et al. (1998) and the suspension was used to inoculate the columns.

\section{Reactor system}

Aquifer columns extracted from the actual contaminated site (Brits, North West Province, South Africa) were installed in the laboratory as continuous-flow columns (Fig. 1). The extracted columns were encased in tight fitting Plexiglas cylinders $(60 \mathrm{~cm}$ long, $5 \mathrm{~cm}$ internal diameter). Five equally spaced longitudinal 
sampling ports were drilled along each column. The columns were capped on both ends with PVC caps with a provision for influent and effluent sampling ports. Before closing the columns on both ends, one of the columns (R3) was sterilised by autoclaving for $20 \mathrm{~min}$ at $121^{\circ} \mathrm{C}$ to serve as an abiotic control. The operational conditions of the experimental columns are shown in Fig. 1.

The aquifer soil columns were then installed vertically on a mounting board. Reservoirs feeding the reactors were interconnected with an overflow to maintain a constant hydraulic head of $76 \mathrm{~cm}$ in all columns. The applied hydraulic head corresponded to the average summer water table above the sample collection depth at the target test site. The reactors (R2) and (R4) were each seeded with $100 \mathrm{~m} \ell$ suspension containing $8 \times$ $10^{10}$ cells of mixed-culture at a very slow rate of $0.28 \mathrm{m \ell} \cdot \mathrm{min}^{-1}$ for $48 \mathrm{~h}$, enough time to allow uniform distribution and adhesion of cells to soil particles. $\mathrm{Cr}(\mathrm{VI})$ loading in the reactor columns was simulated by gravity feeding as in the case of open aquifers at the actual contaminated site. Microcosm reactors were operated as packed-bed reactors at different influent $\mathrm{Cr}(\mathrm{VI})$ concentrations $\left(20-50 \mathrm{mg} \cdot \ell^{-1}\right)$ corresponding to the seasonal change in concentration at the site. Samples withdrawn from the equally-spaced sampling ports and from the effluent port at the bottom were centrifuged at $6000 \mathrm{r} \cdot \mathrm{min}^{-1}(2820 \times g)$ for $10 \mathrm{~min}$ to remove cells and soil particles before analysis.

Since the system is being developed for application in a nutrient-deficient groundwater environment, some reactors were operated without added organic carbon source to test performance under autotrophic conditions and some were operated with carbon sources from decaying roots and leachate from decaying vegetation on the surface. Organic sources were simulated by a layer of sawdust $(2 \mathrm{~cm})$ to continuously leach organics into the soil column. The leachate was characterised by GC/MS and quantified by TOC Analyser to check for biodegradable organic content from the feed stream.

\section{Analytical methods}

\section{Sample pre-concentration and loading}

Volatile organics were mobilised from soil and water samples using a Turbo Matrix 40 Headspace (Perkin-Elmer, Connecticut, USA) equipped with a trap. The organics were extracted by boiling at the headspace oven temperature of $80^{\circ} \mathrm{C}$ for $40 \mathrm{~min}$ at a vial pressure of $206.84 \mathrm{kPa}$ (30 psi) and desorbed onto the GC column at $103.42 \mathrm{kPa}(15 \mathrm{psi})$.

\section{Characterisation of organics}

Organics extracted in the headspace unit above were desorbed from the trap into the PerkinElmer GC/MS system comprising of a Clarus $600 \mathrm{GC}$, and a Clarus 600T Mass Spectrometer (MS) (Perkin Elmer, Connecticut, USA) using helium as carrier gas. The GC was equipped with a Perkin Elmer Elite - 5MS capillary column $(30 \mathrm{~m} \times 0.25 \mathrm{~mm}$ ID $\times 0.5 \mu \mathrm{m}$ fixed phase $)$. Injection port temperature was set at $250^{\circ} \mathrm{C}$. The column oven program was initiated at $40^{\circ} \mathrm{C}$ and ramped at $5^{\circ} \mathrm{C}$ per minute to $150^{\circ} \mathrm{C}$ and at $15^{\circ} \mathrm{C}$ per minute to $250^{\circ} \mathrm{C}$ with a carrier gas split flow of $3 \mathrm{~m} \ell \cdot \mathrm{min}^{-1}$ and a flow rate of $1 \mathrm{m \ell} \cdot \mathrm{min}^{-1}$. The GC detectors were bypassed in this method. The MS method was operated using electron ionisation $\left(\mathrm{EI}^{+}\right)$mode, centroid data setting, with scan duration of $0.3 \mathrm{~s}$ and inter-scan delay of 0.2 s. Degradation intermediates were identified by searching for closest matches in the Wiley Mass Spectral Libraries.

\section{Quantification of organics}

The total carbon content in the organic leachate from natural organic carbon sources was analysed using the Total Organic Carbon (TOC) Analyser (Model TOC-VWP, Shimadzu Corporation, Kyoto, Japan). The TOC analyser was calibrated by dissolving different proportions of a $1000 \mathrm{mg} \cdot \ell^{-1}$ potassium hydrogen phthalate stock solution in concentrations ranging from $0-5 \mathrm{mg} \cdot \ell^{-1}$ in a $100 \mathrm{~m} \ell$ volumetric flask prior analysing for total carbon.

\section{$\mathrm{Cr}(\mathrm{VI})$ and total $\mathrm{Cr}$}

$\mathrm{Cr}(\mathrm{VI})$ was measured using a UV/Vis spectrophotometer (WPA, Light Wave II, Labotech, South Africa) at a wavelength of 540 $\mathrm{nm}(10 \mathrm{~mm}$ light path) after acidification and reaction with 1,5-diphenyl carbazide to produce a purple-pink colour (APHA, 2005). Total Cr was measured at a wavelength of $359.9 \mathrm{~nm}$ using a Varian AA-1275 Series Atomic Adsorption Spectrophotometer (AAS) (Varian, Palo Alto, CA (USA)) equipped with a $3 \mathrm{~mA}$ chromium hollow cathode lamp. Cr(III) was determined as the difference between total $\mathrm{Cr}$ and $\mathrm{Cr}(\mathrm{VI})$ concentration.

\section{Total and viable biomass}

Total biomass was measured as a function of volatile solids (VS) in the reactor. Volatile solids were determined as the loss in dry weight of samples of the known volume after igniting the thoroughly dried sample at $600^{\circ} \mathrm{C}$ in furnace. A conversion factor $f=0.8$ was used to convert VS to total biomass (Reynolds and Richards, 1996). Viable cells were determined using the heterotrophic (pour) plate method and colony counts as described in the Standard Methods for the Examination of Water and Wastewater (APHA, 2005), with the colonies grown on Luria-Bettani (LB) and Plate Count (PC) agar. Samples of known mass collected from the sample ports were suspended in $5 \mathrm{~m} \ell$ sterile BMM and subjected to serial dilution. CFU counts from the top three plates were averaged and the CFU count was converted to mass concentration using a calibration conversion factor of $1.833 \times 10^{-10} \mathrm{mg} \cdot$ cell $^{-1}$ (with $R^{2}=0.997$ ).

\section{Model development}

\section{Diffusion process}

The diffusivity of $\mathrm{Cr}(\mathrm{VI})$ in water was estimated using the Nernst-Haskell equation (Longsworth, 1972):

$$
D_{c}=\frac{\mathrm{RT}}{F^{2}} \cdot \frac{\lambda}{\gamma_{i}}
$$

where:

$$
\begin{aligned}
& D_{c}=\text { diffusion coefficient of } \mathrm{Cr}(\mathrm{VI}) \text { in water }\left(\mathrm{cm}^{2} \cdot \mathrm{s}^{-1}\right) \\
& \mathrm{T}=\text { absolute temperature }(\mathrm{K}) \\
& \mathrm{R}=\text { universal gas constant }\left(\mathrm{J} \cdot \mathrm{mol}^{-1} \cdot \mathrm{K}\right) \\
& F=\text { Faraday's constant }\left(\mathrm{C} \cdot \mathrm{g}^{-1} \cdot \mathrm{mol}\right) \\
& \gamma_{i}=\text { ionic valence }(\text { charge }) \text { of } \mathrm{Cr}(\mathrm{VI})\left(\mathrm{as}_{\mathrm{CrO}_{4}}^{2-}\right) \\
& \lambda=\text { electrolytic conductance }\left(\mathrm{cm}^{2} \cdot \mathrm{ohm}^{-1} \cdot \mathrm{C}^{-1}\right)
\end{aligned}
$$

The conductance was computed from an equivalent conductance $\Lambda=1000 \cdot K^{\prime} / C_{c^{\prime}}$, where $K^{\prime}=$ specific conductance $\left(1 \mathrm{ohm}^{-1} \cdot \mathrm{cm}^{-1}\right)$ estimated from tables of physical properties (Perry, 1997), and $C_{c}=$ electrolyte charge concentration (equivalent charge $\cdot \mathrm{cm}^{-3}$ ). A value of $D_{c}=1.05 \times 10^{-5} \mathrm{~cm}^{2} \cdot \mathrm{s}^{-1}$ was found using a $K^{\prime}$ value of $4.5 \times 10^{-6} \mathrm{ohm} \cdot \mathrm{cm}^{-1}$ determined from 
standard 1 molar $\mathrm{Cr}(\mathrm{VI})$ solutions in water at $25^{\circ} \mathrm{C}$ (Garrels and Christ, 1965).

Mass transport of all dissolved species $\mathbf{u}_{i}$ in water follows Fick's second law of molecular diffusion:

$$
\frac{\partial \mathbf{u}_{i}}{\partial t}=D_{i w} \frac{\partial^{2} \mathbf{u}_{i}}{\partial z^{2}}
$$

where:

$\mathbf{u}_{i}=$ concentration of dissolved species $\left(M L^{-3}\right)$

$D_{i w}=$ diffusivity of dissolved species in water $\left(L^{2} T^{1}\right)$

$t=$ time $(T)$

$z$ is the spatial coordinate $(L)$ for a 1-dimensional diffusion model in the direction of $z$

\section{Hydraulic characteristics}

The void volume available for free flow of water in the soil column decreased as cells grew around the soil particles. This resulted in a decrease in the effective cross-sectional area $[A(t)]$ and constrained flow with increasing time. The initial value of $A(t)$ before biomass attachment is computed as:

$$
A(0)=\frac{\pi(\mathrm{ID})^{2}}{4} \cdot\left(\frac{V-V_{s}}{V}\right)
$$

where:

$V=\pi(\mathrm{ID})^{2} \cdot h / 4$, the empty-column volume $\left(L^{3}\right)$

$V_{\mathrm{s}}=$ volume occupied by impermeable solids $\left(L^{3}\right)$

ID = internal diameter of the reactor column $(L)$

$h=$ height of the packed-bed $(L)$

The available cross-sectional area $\mathrm{A}(t)$ affects the interstitial fluid velocity $u\left(L T^{1}\right)$ and the stagnant liquid layer around the soil particles $L_{w}$. The thickness of the stagnant liquid layer is estimated using the Frössling's correlation (Frössling, 1938):

$$
L_{w}=\left[0.6 \cdot\left(\frac{1}{D_{i_{w}}{ }^{1 / 3} v^{1 / 6}}\right) \cdot\left(\frac{u^{1 / 2}}{d_{p}{ }^{1 / 2}}\right)\right]^{-1}
$$

where:

$D_{i w}=$ diffusion coefficient of dissolved species in water

$\left(L^{2} T^{-1}\right)$

$u=Q_{c} / A(t)$, the interfacial discharge rate $\left(L T^{1}\right)$

$Q_{c}=Q_{i n}+Q_{R}$, the combined flow across the bulk liquid zone

$\left(L^{3} T^{1}\right)$, where $Q_{i n}=$ feed flow rate $\left(L^{3} T^{1}\right)$ and $Q_{R}=$ recycle flow rate $\left(L^{3} T^{-1}\right)$

$d_{p}=$ average particle size $(L)$

$v=$ kinematic viscosity $\left(L T^{-1}\right)$

$A(t)=$ effective cross-sectional area of the reactor $\left(L^{2}\right)$

\section{Reactor mass balance and kinetics}

Removal of dissolved species over time across the bulk liquid of the soil column is represented by a set of ordinary differential equations consisting of the following aspects in its mass balance equation:

\section{- Advection}

$$
\frac{-d(C V)}{d t}=A u\left(C_{i n}-C\right)
$$

where:

$C=$ effluent $\mathrm{Cr}(\mathrm{VI})$ concentration $\left(M L^{-3}\right)$

$V=$ volume of the reactor $\left(L^{3}\right)$

$C_{i n}=$ influent $\mathrm{Cr}(\mathrm{VI})$ concentration $\left(M L^{-3}\right)$
$Q(A u)=$ influent flow rate $\left(L^{3} T^{1}\right)$

$A=$ cross sectional area of reactor $\left(L^{2}\right)$

$u=$ velocity of the flow $\left(L T^{1}\right)$

$t=$ time $(T)$

- Reduction by microbial kinetics (reaction process) The associated rate kinetics, which were based on noncompetitively inhibited rate kinetics, were proposed by Molokwane (2010). In Molokwane's work, a finite Cr(VI) reduction capacity was assumed in immobilised cells. The acclimated cells demonstrated the capability to function normally until a toxicity threshold concentration of approximately $100 \mathrm{mg} \cdot \ell^{-1} \mathrm{Cr}(\mathrm{VI})$.

$\frac{d C}{d t}=-\frac{k_{m c} \cdot C}{K^{1-C r / C_{i n}} \cdot\left(K_{c}+C\right)}\left(X_{a}-\frac{C_{i n}-C}{R_{c}}\right)$

$\frac{d X}{d t}=Y\left(\frac{k_{m s} S}{K_{s}-S}\right)-k_{d} X$

where:

$K=$ dimensionless $\mathrm{Cr}(\mathrm{VI})$ inhibition factor $\left(M M^{-1}\right)$

$K_{c}=$ half-velocity coefficient $\left(M L^{-3}\right)$

$X_{a}^{c}=$ concentration of $\mathrm{Cr}(\mathrm{VI})$ reducing cells $\left(M L^{-3}\right)$

$C_{r}^{a}=$ inhibition threshold concentration $\left(M L^{-3}\right)$

$C_{i n}=$ influent $\mathrm{Cr}(\mathrm{VI})$ concentration $\left(M L^{-3}\right)$

$R_{c}=\mathrm{Cr}(\mathrm{VI})$ reduction capacity of cells [g Cr(VI) reduced/g immobilised cells] $\left(M M^{-1}\right)$

$Y=$ cell yield coefficient $\left(M M^{-1}\right)$

$k_{m}=$ maximum specific substrate utilisation rate coefficient $\left(T^{1}\right)$

$k_{m c}=$ maximum specific $\mathrm{Cr}(\mathrm{VI})$ reduction rate $\left(T^{1}\right)$

$k_{d}=$ cell death rate coefficient $\left(T^{1}\right)$

$X=$ viable cell concentration $\left(M L^{-3}\right)$

Due to space limitations in the reactor, cells may only grow to a certain maximum concentration $\left[X_{\max }\right]$. The time at which the cells reach the maximum allowable concentration is dependent on initial cells, $\mathrm{Cr}(\mathrm{VI})$ toxicity and hydraulic loading rate. These conditions allow us to simplify the cell growth term (Eq. 7) to the following logistic function:

$$
X=X_{0}+\frac{X_{\max }}{1+\left(\frac{t}{t_{0}}\right)^{b}}
$$

where:

$X=$ viable cell concentration $\left(M L^{-3}\right)$ at any time $t(T)$

$X_{\max }=$ maximum attainable viable cell concentration $\left(M L^{-3}\right)$ in the microcosm

$X_{0}=$ initial viable cell concentration $\left(M L^{-3}\right), t_{0}=$ logistic interval $(T)$

$b=$ pitch (dimensionless).

\section{- Diffusion process}

Mass transfer within the attached cell layer is described by Fick's law for dispersion as presented in (Eq.(2)). The contaminant flux across the stagnant layer to the biofilm is a function of the contaminant dispersion coefficient and concentration and is represented as:

$\frac{d(C V)}{d t}=-D_{i_{w}} \frac{d C}{d z}=-\frac{D_{i w}}{L_{w}} A_{f}\left(C_{B}-C_{s}\right)=-j_{C} \cdot A_{f}$

where:

$D_{i w}=$ dispersion coefficient of $\mathrm{Cr}(\mathrm{VI})$ in water $\left(L^{2} T^{1}\right)$ 
$d C / d z=\mathrm{Cr}(\mathrm{VI})$ concentration gradient $\left(M L^{-3} L^{-1}\right)$

$L_{W}=$ thickness of stagnant layer $(L)$

$C_{B}=$ bulk liquid $\mathrm{Cr}(\mathrm{VI})$ concentration $\left(M L^{-3}\right)$

$j_{C}=$ flux of dissolved species into the biofilm $\left(M L^{-2} T^{1}\right)$

$C_{S}=\mathrm{Cr}(\mathrm{VI})$ surface concentration $\left(M L^{-3}\right)$

NB: In most mass transfer-limited reactions $C_{B} \gg C_{s}$, therefore $C_{s}$ is negligible.

\section{- Adsorption process}

$\frac{-d C}{d t}=k_{a d}\left(C_{e q}-C\right)=-q_{C}$

where:

$k_{a d}=$ adsorption rate coefficient $\left(T^{1}\right)$

$C_{e q}^{a d}=$ equilibrium concentration at surface area $\left(M L^{-3}\right)$

$C^{e q}=\mathrm{Cr}(\mathrm{VI})$ concentration at any time $\left(M L^{-3}\right)$

$q_{c}=$ rate of $\mathrm{Cr}(\mathrm{VI})$ removal by adsorption $\left(T^{1}\right)$

The adsorption and diffusion processes are facilitated by the terms $\left(q_{c}\right)$ and $\left(j_{c}\right)$, respectively, and the reaction process is represented by the term $\left(r_{c}\right)$ which represents reaction by biomass $(X)$. The term $\left(q_{c}\right)$ can approach equilibrium easily whereas the terms $(r)$ and $(j)$ depend on the active biomass. The overall mass balance for dissolved species (Eqs (5) to (10)) and biomass is given by the equation below:

$\frac{\partial(\mathbf{C} V)}{\partial t}=Q\left(\mathbf{C}_{i n}-\mathbf{C}\right)-\mathbf{r}_{\mathrm{c}} \cdot V_{B}-\left(\mathbf{j}_{\mathrm{c}}+\mathbf{q}_{\mathrm{c}}\right) \cdot A_{f}$

$\frac{\partial\left(\mathbf{x}_{B} V\right)}{\partial t}=-Q \mathbf{x}_{B}+\lambda(u) \cdot \mathbf{x}_{f} L_{f} A_{f}-k_{d} \mathbf{x}_{B} V$

where:

$j_{c}=$ flux of dissolved species into the biofilm $\left(M L^{-2} T^{-1}\right)$

$r_{c}=$ rate of removal of dissolved species by suspended cells in the bulk liquid $\left(M L^{-3} T^{-1}\right)$

$\lambda=$ cell detachment rate coefficient $\left(T^{1}\right)-$ a function of the interfacial velocity $u\left(L T^{-1}\right)$

$k_{d}=$ cell death rate coefficient $\left(T^{1}\right)$

$A_{f}=$ available surface area $\left(L^{2}\right)$

$V=$ the bulk liquid volume $\left(L^{3}\right)$

$X_{B}=$ biomass density in the bulk liquid $\left(M L^{-3}\right)$

$X_{f}=$ biomass density in the biofilm zone $\left(M L^{-3}\right)$

$L_{f}=$ thickness of biofilm layer $(L)$.

\section{Quasi-steady state kinetics}

Steady-state conditions were evaluated with the soil column as a plug flow system with incremental loading per mass of reactor:

$$
-\frac{d F_{c}}{d W}=\gamma_{c}
$$

where:

$F_{c}=$ molar loading rate of $\mathrm{Cr}(\mathrm{VI})\left(M T^{1}\right)$

$\stackrel{c}{W}=$ mass of aquifer soil particles $(M)$

$\gamma_{c}=$ reaction rate $\left(M L^{-3} T^{-1}\right)$

Under quasi-steady-state conditions biomass, adsorption and diffusion process in Eqs( 9) and (10) reached equilibrium. Therefore, the local reaction rate at a particular point can be simplified in terms of the $\mathrm{Cr}(\mathrm{VI})$ reduction capacity of individual cells. The reaction was originally first order but was slowed down by the toxicity of the reactant; a mixed kinetic may be represented as follows: $-\gamma_{c}=k C\left(1-\frac{C}{C_{r}}\right)^{n}$

(Levenspiel, 1999)

where:

$C=\mathrm{Cr}(\mathrm{VI})$ concentration along the reactor column $\left(M L^{-3}\right)$

$C_{r}=\mathrm{Cr}(\mathrm{VI})$ toxicity threshold coefficient $\left(M L^{-3}\right)$

$k=$ reaction rate coefficient $\left(L^{3} M^{-1} T^{-1}\right)$

$n=$ semi-empirical dimensionless variable $\left(M M^{-1}\right)$

The mass $(W)$ and loading rate $\left(F_{c}\right)$ are defined as $\rho A_{f} L$ and $Q_{i n} C$, respectively, so that the differential term can be expressed in terms of $d C / d L$ and the whole reaction term can be simplified by rearranging terms:

$$
-\frac{d C}{d L}=k C\left(\frac{\rho A_{f}}{Q_{i n}}\right)\left(1-\frac{C}{C_{r}}\right)^{n}
$$

where:

$C=\mathrm{Cr}(\mathrm{VI})$ concentration $\left(M L^{-3}\right)$ at any point $(L)$ along the reactor column

$k=$ reaction rate coefficient $\left(L^{3} M^{-1} T^{1}\right)$

$Q_{\text {in }}=$ hydraulic loading rate $\left(L^{3} T^{-1}\right)$

$\rho=$ density of aquifer soil particles $\left(M L^{-3}\right)$

$A_{f}=$ available surface area $\left(L^{2}\right)$

$L=$ length of the reactor $(L)$

The parameters $\rho, Q_{i n}$, and $C_{r}$ are constant whereas the surface area $A_{f}$ varies with time as described in Eq. (3).

Assumptions governing the model in Eq.(15) are as follows:

- There is no mixing in the axial direction, this implies that molecular and/or turbulent mass dispersion is negligible in flow direction

- Uniform properties in the direction perpendicular to the flow (flow is 1-dimensional)

- The net growth of bacteria is zero near steady-state, i.e., $\mathrm{Cr}(\mathrm{VI})$ reduction is by resting cells

- The system is a homogenous catalytic system

\section{RESULTS AND DISCUSSION}

\section{$\mathrm{Cr}(\mathrm{VI})$ reduction kinetics in columns}

Spatial and temporal variation of $\mathrm{Cr}(\mathrm{VI})$ in the columns inoculated with mixed-culture of bacteria from the dried sludge samples collected within the vicinity of the contaminated site was evaluated under both carbon source and non-carbon source conditions. Complete $\mathrm{Cr}(\mathrm{VI})$ reduction was observed in the inoculated carbon source reactor after $102 \mathrm{~h}$ of operation while a $\mathrm{Cr}(\mathrm{VI})$ removal efficiency of $69.5 \%$ was observed in the inoculated non-carbon source reactor at the same time of operation (Fig. 2A-B). These results suggest that the presence of the carbon source greatly enhances or stimulates the performance of $\mathrm{Cr}(\mathrm{VI})$ reduction in a biological system.

Additionally, data collected from equally-spaced longitudinal sampling ports of columns inoculated with a mixedculture of bacteria demonstrated significant $\mathrm{Cr}(\mathrm{VI})$ reduction with maximum observable rate of approximately $2 \mathrm{mg} \cdot \ell^{-1} \cdot \mathrm{h}^{-1}$ between 50 and $75 \mathrm{~h}$, with a removal efficiency of about $70 \%$ (Fig. 2A-B). These results demonstrate that the effluent $\mathrm{Cr}(\mathrm{VI})$ concentration in the columns inoculated with mixed-culture of bacteria did not stabilise until a quasi-steady state was achieved. The insignificant $\mathrm{Cr}(\mathrm{VI})$ reduction $(\leq 5 \%)$ along the column at quasi-steady state, i.e. between 75 and $102 \mathrm{~h}$ may be 

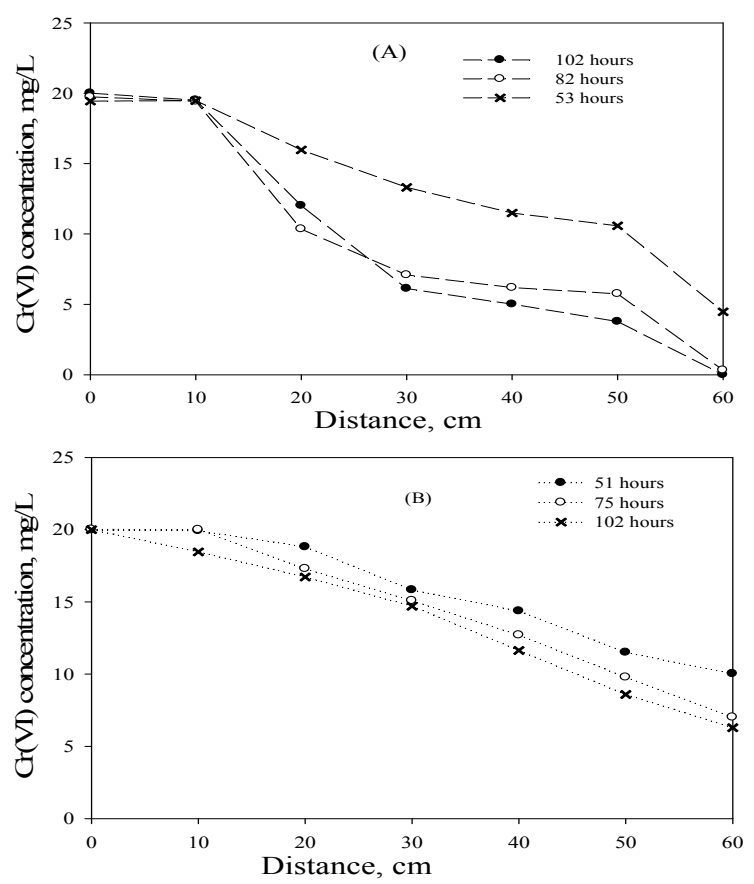

Figure 2

Performance of columns inoculated with mixed-culture of bacteria from the sludge samples in reducing $\mathrm{Cr}(\mathrm{VI})$ feed concentration of $20 \mathrm{mg} \cdot \ell^{-1}$ in (A) $C$-source reactor $(+C S)$, and (B) non $C$-source reactor $(-C S)$

associated with $\mathrm{Cr}(\mathrm{VI})$ inhibitory effects on $\mathrm{Cr}(\mathrm{VI})$-reducing bacteria, loss of $\mathrm{Cr}(\mathrm{VI})$ reduction capacity due to blockage of pores with $\mathrm{Cr}$ (III) precipitate, and/or the saturation of physical chemical process-adsorption and biosorption over time.

The performance of $\mathrm{Cr}(\mathrm{VI})$ reduction between the native soil culture column amended with sawdust and the sterilecontrol column was also evaluated. Insignificant $\mathrm{Cr}(\mathrm{VI})$ reduction was observed in both columns with a removal efficiency of about $10 \%$ for the native soil culture column and only $2 \%$ for the sterile-control column after $102 \mathrm{~h}$ of operation (Fig. $3 \mathrm{~A}-\mathrm{B})$. Pronounced $\mathrm{Cr}(\mathrm{VI})$ reduction observed in columns inoculated with a mixed-culture of bacteria, as compared to the native soil culture column, indicated the prominence of in situ bioremediation using target $\mathrm{Cr}(\mathrm{VI})$-reducing species. The insignificant $\mathrm{Cr}(\mathrm{VI})$ reduction observed in the native soil culture column amended with sawdust as carbon source indicates that the native species present in the soil samples may not be $\mathrm{Cr}(\mathrm{VI})$ reducers but rather $\mathrm{Cr}(\mathrm{VI})$ resistors, as they remained persistent in the column even after long periods of exposure to $\mathrm{Cr}(\mathrm{VI})$ loadings. Additionally, insignificant $\mathrm{Cr}(\mathrm{VI})$ reduction in a sterile-control (heat-killed cells) reactor over time indicated that the abiotic processes are negligible.

\section{Evaluation of internal processes}

\section{Parameter optimisation and model evaluation}

The effluent $\mathrm{Cr}(\mathrm{VI})$ concentration across the reactor at transient-state was evaluated using the model defined in Eq. (11) The kinetic parameters were obtained by performing a nonlinear regression analysis using AQUASIM 2.0 (a computer program for identification and simulation of aquatic systems). The reliability of the model was demonstrated by near-constant optimisable parameters under different loading conditions, as shown in Table 2A. Conversely, spatial modelling of $\mathrm{Cr}(\mathrm{VI})$
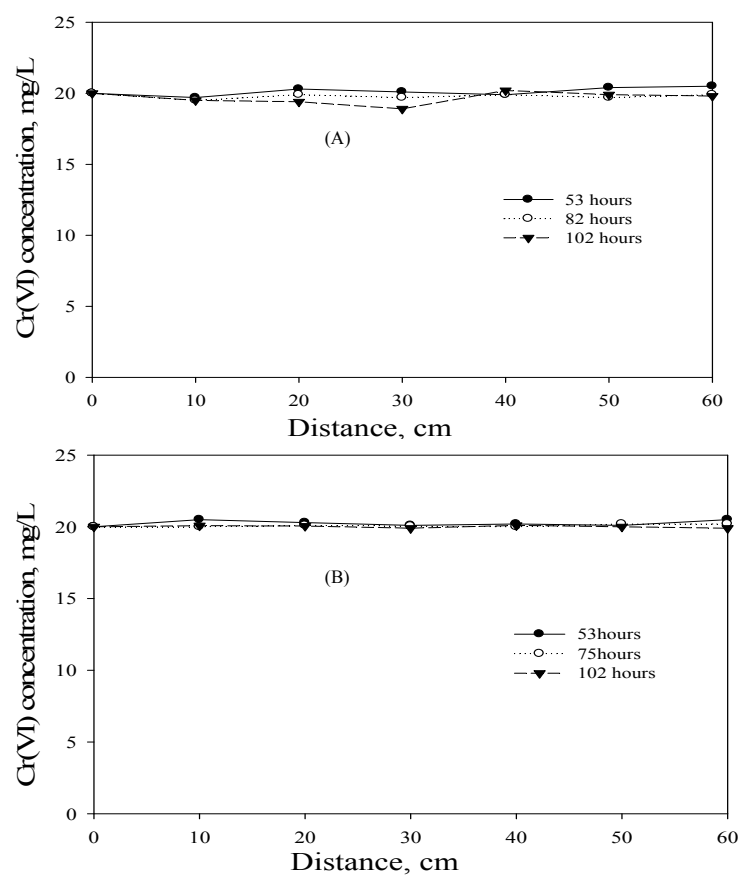

Figure 3

Performance of $\mathrm{Cr}(\mathrm{VI})$ reduction in $(A)$ native soil culture $(+C S)$ column, and (B) sterile-control column at $20 \mathrm{mg} \cdot \ell^{-1} \mathrm{Cr}(\mathrm{VI})$

concentration profile across the reactor was evaluated using the model developed under near steady-state conditions (Eq. 15).

The model was initially tested with data from the experimental run of $50 \mathrm{mg} \cdot \ell^{-1} \mathrm{Cr}(\mathrm{VI})$ in the inoculated columns. The experimental run at this concentration was treated as a control due to insignificant $\mathrm{Cr}(\mathrm{VI})$ reduction $(\leq 10 \%)$ observed under these loading conditions after operation. The kinetic parameters for the model developed under near steady-state conditions were obtained using a computer program for solving numerical problems (Octave 3.0). Trial values of the optimisable kinetic parameters were initially adapted from the transient-state kinetic parameters and then adjusted as a result of low levels of biomass under near steady-state conditions. The optimum kinetic parameters ( $k$ and $n$ ) obtained from the initially tested $\mathrm{Cr}(\mathrm{VI})$ concentration under quasi-steady-state conditions were then used to simulate the experimental data under different loading conditions in both carbon source and non-carbon source columns. The model successfully captured the trends of $\mathrm{Cr}(\mathrm{VI})$ response profiles under quasi-steady-state conditions for different loading conditions. The reliability of the model was demonstrated by near-constant optimisable parameters under different loading conditions, as shown in Table 2B.

\section{Performance evaluation under near steady-state conditions}

The quasi-steady-state model was evaluated in the column inoculated with mixed-culture of bacteria under both carbon and non-carbon source conditions (Fig. 4A-C). Cr(VI) toxicity threshold; $C_{r}$ in the model was assumed to be $50 \mathrm{mg} \cdot \ell^{-1}$ based on the experimental data obtained at this concentration. Fig. $4 \mathrm{~A}$ demonstrates that the inhibitory effects of $\mathrm{Cr}(\mathrm{VI})$ removal in a non-carbon source column occurs at a faster rate than in the carbon source reactor. This indicates that the presence of organic compounds in the carbon source reactor enhances 


\begin{tabular}{|c|c|c|c|c|}
\hline \multicolumn{5}{|c|}{$\begin{array}{l}\text { TABLE 2A } \\
\text { Optimum kinetic parameter values for the carbon source }(+C S) \text { and non-carbon source } \\
\text { reactor }(-\mathrm{CS}) \text { over time at initial } \mathrm{Cr}(\mathrm{VI}) \text { concentration ranging from } 20-50 \mathrm{mg} \cdot \ell^{-1}\end{array}$} \\
\hline \multirow[t]{2}{*}{ Symbol } & Description & $\begin{array}{c}\text { Constraints } \\
\text { [lower, upper] }\end{array}$ & $\begin{array}{c}\text { (+)CS column } \\
\text { optimised value }\end{array}$ & $\begin{array}{c}\text { (-)CS column } \\
\text { optimised value }\end{array}$ \\
\hline & Biological parameters & & & \\
\hline$C\left(\mathrm{mg} \cdot \ell^{-1}\right)$ & State variable & --- & $1 \times 10^{-6}$ & $1 \times 10^{-6}$ \\
\hline$C_{r}\left(\mathrm{mg} \cdot \ell^{-1}\right)$ & $\mathrm{Cr}(\mathrm{VI})$ toxicity threshold & --- & 50 & 50 \\
\hline$\mu\left(\mathrm{h}^{-1}\right)$ & biomass growth rate & {$[0,10000]$} & 0.028 & 0.018 \\
\hline$k_{d}\left(\mathrm{~h}^{-1}\right)$ & Cell death rate coefficient & {$[0,10000]$} & 0.0025 & 0.0031 \\
\hline$k_{m c}\left(\mathrm{~h}^{-1}\right)$ & $\mathrm{Cr}(\mathrm{VI})$ reduction rate & {$[0,0.02]$} & 0.0051 & 0.0010 \\
\hline$K_{c}\left(\mathrm{mg} \cdot \ell^{-1}\right)$ & Half velocity coefficient & {$[0,15]$} & 11.272 & 12.51 \\
\hline \multirow[t]{2}{*}{$R_{r}\left(\mathrm{mg} \cdot \mathrm{mg}^{-1}\right)$} & Reduction capacity of cells & {$[0,0.5]$} & 0.283 & 0.099 \\
\hline & Physical parameters & & & \\
\hline$Q_{i n}\left(\ell \cdot h^{-1}\right)$ & Inflow rate & --- & 0.015 & 0.015 \\
\hline$A\left(\mathrm{~m}^{2}\right)$ & Cross sectional area & --- & 0.00196 & 0.00196 \\
\hline$D_{i w}\left(\mathrm{~m}^{2} \cdot \mathrm{h}^{-1}\right)$ & Dispersion/diffusion & {$[0,100]$} & 95.418 & 11.708 \\
\hline
\end{tabular}

\begin{tabular}{|l|l|c|c|}
\hline \multicolumn{4}{|c|}{ TABLE 2B } \\
\multicolumn{3}{|c|}{$\begin{array}{l}\text { Optimum kinetic parameter values at quasi-steady state in a carbon source and a } \\
\text { non-carbon source reactor at initial Cr(VI) concentration ranging from 20-50 mg } \ell^{-1}\end{array}$} \\
\hline Kinetic parameter & Description & $\begin{array}{c}\text { Carbon source reactor } \\
+\mathrm{CS})\end{array}$ & $\begin{array}{c}\text { Non-carbon source } \\
\text { reactor }(-\mathrm{CS})\end{array}$ \\
\hline$k\left(\ell \cdot \mathrm{mg}^{-1} \cdot \mathrm{h}^{-1}\right)$ & Reaction rate coefficient & $5.2 \times 10^{-8}$ & $9.9 \times 10^{-9}$ \\
\hline$n\left(\mathrm{mg} \cdot \mathrm{mg}^{-1}\right)$ & Semi-empirical variable & 2 & 1 \\
\hline
\end{tabular}

$\mathrm{Cr}(\mathrm{VI})$ reduction activity by stimulating microbial cell activity. It is also shown in Table 2A and Table 2B that minor adjustments of the kinetic parameter, $k$, were achieved under noncarbon source conditions as a result of slower reaction rate in the absence of carbon source. The toxicity term in the model, suggests that:

$$
\left(1-\frac{\mathrm{C}}{\mathrm{C}_{\mathrm{r}}}\right)^{\mathrm{n}} \rightarrow 0 \text { as } n \rightarrow \infty
$$

The above term implies that the greater the value of $(n)$ in the biological system, the slower the rate at which $\mathrm{Cr}(\mathrm{VI})$ toxicity in the cells is approached. As a result of slower $\mathrm{Cr}(\mathrm{VI})$ toxicity rates achieved in cells at higher $(n)$ values, the subsequent inhibitory effects of $\mathrm{Cr}(\mathrm{VI})$ reduction by $\mathrm{Cr}(\mathrm{VI})$-reducing culture in the system are also approached at a slower rate.

\section{Evaluation of organics in the sawdust}

In order to increase the rate of $\mathrm{Cr}(\mathrm{VI})$ reduction in the inoculated column, sawdust which simulated the carbon source from decaying vegetation within the contaminated site was introduced in the column. The results from TOC analyser showed that at the initial time of incubation $\left(t_{0}\right)$, the total amount of organic carbon in the leachate sample was $268.7 \mathrm{mg} \cdot \ell^{-1}$ and then decreased to $198.3 \mathrm{mg} \cdot \ell^{-1}$ after 12 days of incubation, suggesting that sawdust contain certain organic compounds which may be biodegradable. Additionally, GC/MS also confirmed that certain organic compounds in the sawdust leachate, such

\section{Figure 4 (right)}

Simulation of $\mathrm{Cr}(\mathrm{VI})$ effluent over length under (A) non-carbon source condition, (B) and (C) carbon source condition. The experimental data are the average values of the last 3 sampling times in which the quasisteady state was achieved in the column.
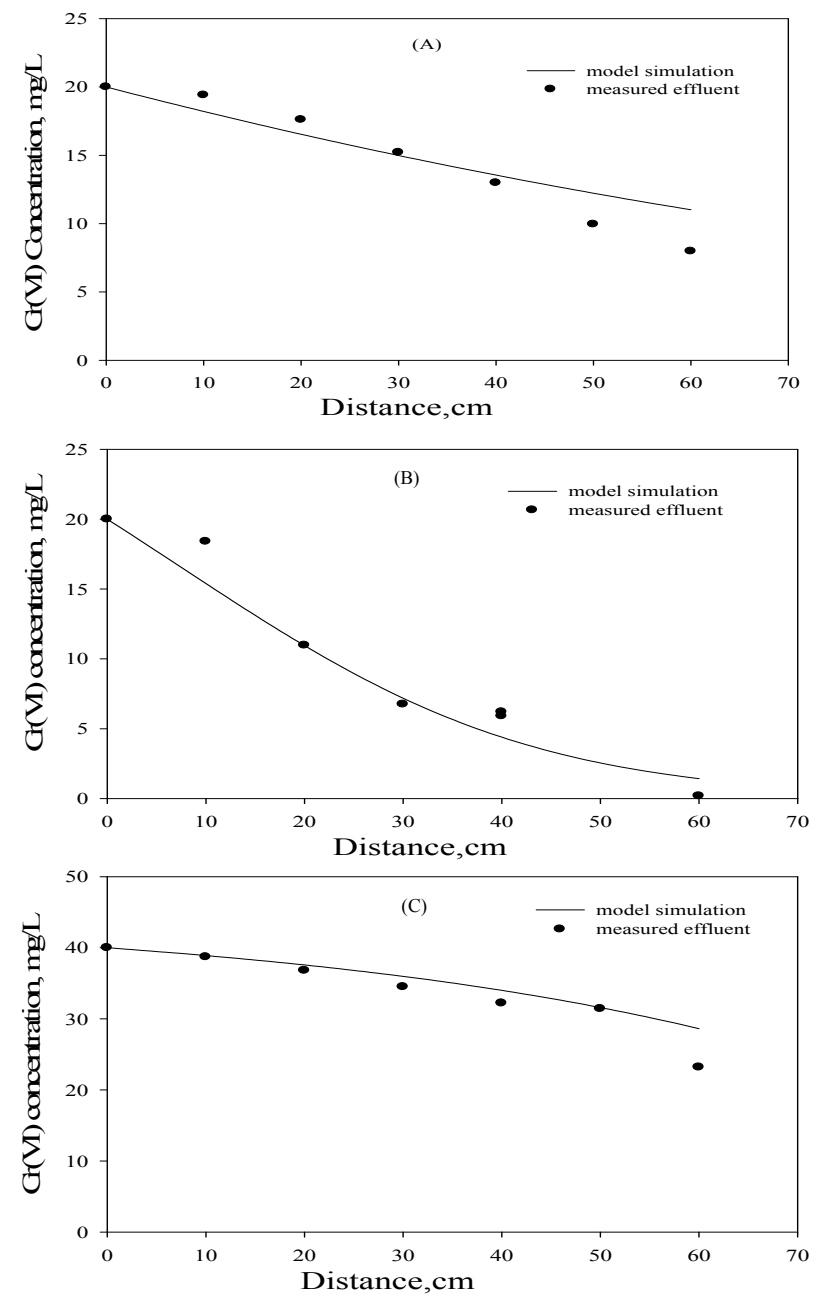

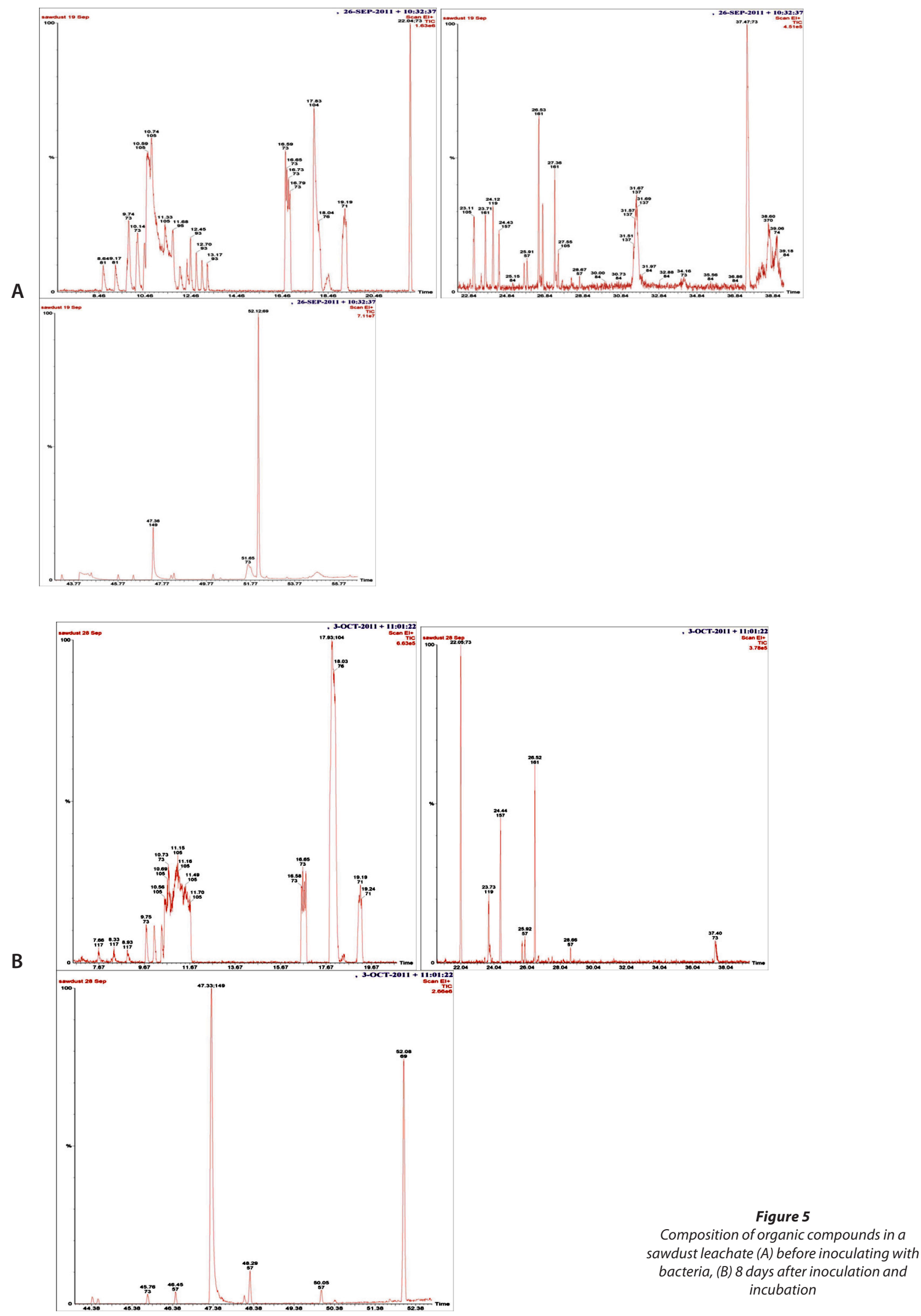

http://dx.doi.org/10.4314/wsa.v40i2.18 Available on website http://www.wrc.org.za 


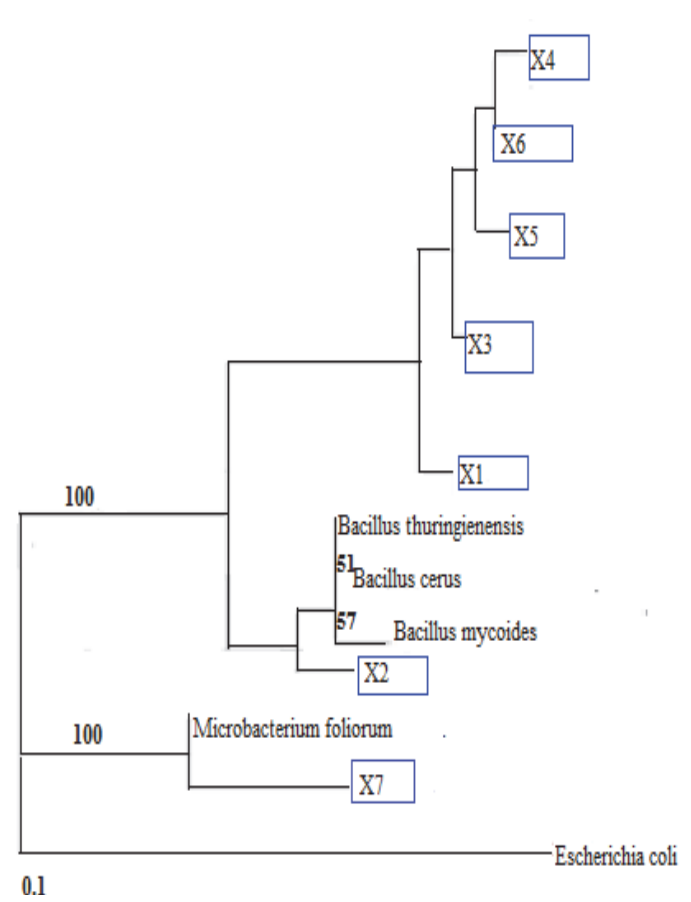

0.1

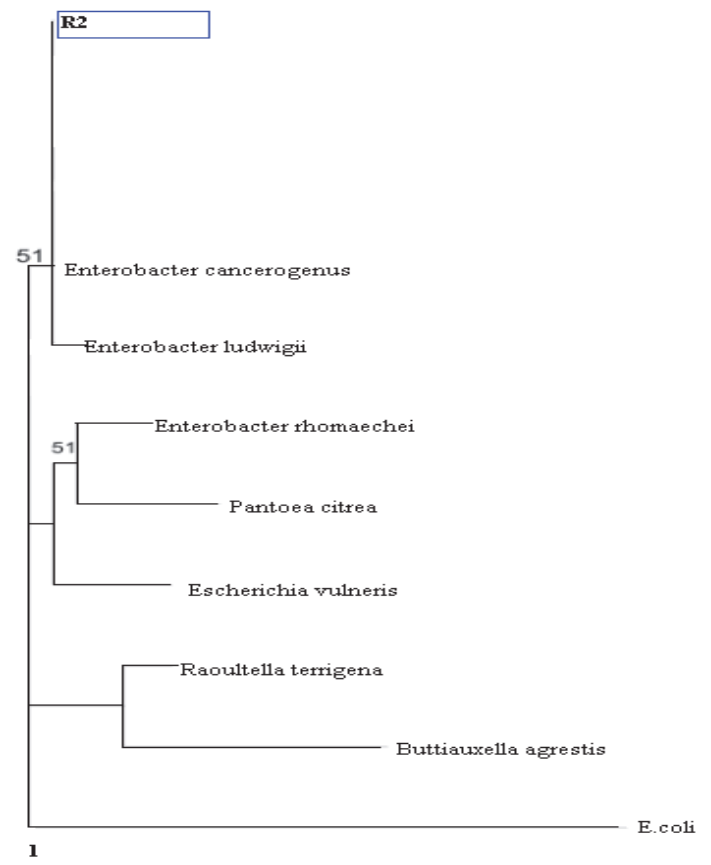

as 1-ethyl-3-vinyl, mercaptoacetic acid, Frenchol, and Bicyclo 2.2.1 heptane of molecular weight $161 \mathrm{~g} \cdot \mathrm{mol}^{-1}, 73 \mathrm{~g} \cdot \mathrm{mol}^{-1}, 81$ $\mathrm{g} \cdot \mathrm{mol}^{-1}$, and $95 \mathrm{~g} \cdot \mathrm{mol}^{-1}$ may be partially degradable, as they were observed to be slowly disappearing in a sawdust leachate over time (Fig. 5A-B).

\section{Microbial culture dynamics}

\section{Characterisation of initially inoculated microcosm bacteria}

The mixed-culture of bacteria used for column inoculation was isolated under micro-aerobic conditions from the dried sludge. The predominant species under these conditions were the Gram-positive Bacilli. A partial sequence of 16S rRNA matched the Bacillus groups - Bacillus cereus ATCC 10987, Bacillus cereus 213 16S, Bacillus thuringiensis, Bacillus mycoides, and
Figure 6

Phylogenetic tree of inoculated bacterial species in the columns (R2 and R4) (a) before loading $\mathrm{Cr}(\mathrm{VI})$, (b and c) persistent bacterial species after operation derived from the $16 \mathrm{~S}$ rRNA gene sequence,

Bacillus sp. and

Enterobacter sp.
2 Microbacterium groups - Microbacterium foliorum and Microbacterium sp. S15-M4.

\section{Characterisation of microcosm bacteria after of operation}

After 7 weeks of microcosm operation under oxygen-stressed conditions, a microbial community shift was expected in the non-sterile soil reactors inoculated with mixed-culture of bacteria from the dried sludge (R2 and R4), as the soil samples themselves contain a wide range of soil-dwelling species of bacteria (native soil culture). The direct measurement of viable cell concentration was challenging in the reactor since the majority of microbial species were not culturable using the conventional methods. The microbial dynamics monitored by the $16 \mathrm{~S}$ rRNA fingerprinting method showed a decrease in culturable species. After exposure to $\mathrm{Cr}(\mathrm{VI})$ for 7 weeks the only serotypes which persisted, either through resilience against toxicity or through adaptation to changing conditions in the soil columns inoculated with mixed-culture of bacteria, were Enterobacter sp., $B$. cereus, and B. thuringiensis (Fig. 6). Both these Bacilli species are well known $\mathrm{Cr}(\mathrm{VI})$-reducing species (Faisal and Hasnain, 2010; Francisco et al., 2002).

\section{CONCLUSION}

Microcosm experiments show that it is possible to introduce microbial cultures, both pure and mixed-cultures of bacteria, into the environment in a controlled manner to successfully achieve $\mathrm{Cr}(\mathrm{VI})$ reduction in flowing water. Compared to the indigenous soil culture which insignificantly removed $\mathrm{Cr}(\mathrm{VI})$ in the system, even in the presence of the added carbon source, the mixed-culture of bacteria from the dried sludge samples collected within the vicinity of a contaminated site was able to sustain high $\mathrm{Cr}(\mathrm{VI})$ removal at $40 \mathrm{mg} \cdot \ell^{-1}$, which is the highest groundwater $\mathrm{Cr}(\mathrm{VI})$ concentration at the study site. Although the microbial culture showed good $\mathrm{Cr}(\mathrm{VI})$ reduction capacity, the application of a biological barrier system for in situ bioremediation of $\mathrm{Cr}(\mathrm{VI})$ remained a challenge due to foreseeable blockage by $\mathrm{Cr}(\mathrm{OH})_{4}$ species in the barrier zone. The model 
developed in this study under quasi-steady-state conditions, which is incorporated with flow characteristics and inactivation term $\left(C_{r}\right)$, successfully predicted the effluent $\mathrm{Cr}(\mathrm{VI})$ concentration profiles in the column inoculated with a mixed-culture of bacteria for different loading conditions, with a $R^{2}$ value of 95\%. Kinetic parameters obtained in the finite difference model showed highest removal rate in the column inoculated with a mixed-culture of bacteria in the presence of non-toxic carbon source, sawdust, than in the inoculated column without carbon source. These results indicate that the rate of $\mathrm{Cr}(\mathrm{VI})$ reduction in the column inoculated with target $\mathrm{Cr}(\mathrm{VI})$-reducing species from the dried sludge samples may be limited by the substrate concentration in the system, which stimulates or encourages microbial activity. Modification of the model for application in engineering biological systems will facilitate final scale-up and operation of microbial barriers in the field.

\section{ACKNOWLEDGEMENTS}

The research was funded partially through the National Research Foundation (NRF) Incentive Funding for Rated Researchers, Grant No. IFR2010042900080 awarded to Evans MN Chirwa of the University of Pretoria.

\section{REFERENCES}

ALLEN H, GARRISON A and LUTHER IG (1998) Metals in Soil Surface. Sleeping Beer Press, New York, NY.17.

APHA (2005) Standard Methods for the Examination of Water and Wastewater (21 $1^{\text {st }}$ edn.). In: Eaton AD, Clesceri LS, Rice EW, Greenberg AE and Franson MAH (eds.). American Public Health Association, American Water Works Association, Water Environment Federation, USA.

BARAL A and ENGELKEN RD (2002) Chromium-based regulations and greening in the metal finishing industries in the USA. Environ. Sci. Polic. 5 (2) 121-133.

BONI MR and SBAFFONI S (2009) The potential of compost-based biobarriers for $\mathrm{Cr}(\mathrm{VI})$ removal from contaminated groundwater: Column test. J. Hazardous Mater. 166 (2-3) 1087-1095.

BLOWES D (2002) Environmental chemistry: tracking hexavalent chromium in groundwater. Science 295 (5562) 2024-2025.

CAGLIERI A, GOLDONI M, ACAMPA O, ANDREOLI R, VETTORI MV, CARRADI M, APOSTOLI P and MUTTI A (2006) The effect of inhaled chromium on different exhaled breath condensate biomarkers among chrome-plating workers. Environ. Health Perspect. 114 (4) 542-546.

CHEUNG KH and GU JD (2007) Mechanism of hexavalent chromium detoxification by microorganisms and bioremediation application potential: a review. Int. Biodeter. Biodegr. 59 (1) 8-15.

CHIRWA EMN and MOLOKWANE PE (2011) Biological Cr(VI) reduction: Microbial diversity, kinetics and biotechnological solutions to pollution. In: Sofo A (ed.) Biodiversity. InTech Online Publishers, United Kingdom.

DWAF (DEPARTMENT OF WATER AFFAIRS AND FORESTRY, SOUTH AFRICA) (2005) Pollution of chrome-6 in the Crocodile River between Brits and the Roodekopjies Dam. Press Release by the Department of Water Affairs and Forestry, 23 December 2005. DWAF, Pretoria.

EGWUONWU GN, OLABODE VO, BUKAR PH, OKOLO VN and ODUNZE AC (2011) Characterization of topsoil and groundwater at leather industrial area, Challawa, Kano, Northern Nigeria. The Pacific J. Sci. Technol. 12 (1) 628-641.

FAISAL M and HASNAIN S (2010) Detoxification of Cr(VI) by Bacillus cereus S-6. Res. J. Microbiol. 7 (5) 651-656.

FEDERAL REGISTER (2004) Occupational Safety and Health Administration. Occupational Exposure to Hexavalent Chromium. 69 Federal Register 59404, 4 October 2004.

FRANCISCO R, ALPOIM MC and MORAIS PV (2002) Diversity of chromium-resistant and chromium-reducing bacteria in a chromium-contaminated activated sludge. J. Appl. Microbiol. 92 (5) 837-843.

FROSSLING N (1938) Of [Over] the volatilization of falling drops. Gerlands Beitréage Geophys. 52 170-216 (in German).

GARRELS RM and CHRIST CL (1965) Solutions, Minerals and Equilibria. Harper and Row Publishers, New York. 403-435.

GONZALEZ CF, ACKERLEY DF, PARK CH and MATIN A (2003) A soluble flavoprotein contributes to chromate reduction and tolerance by Pseudomonas putida. Acta Biotechnol. 23 (2-3) 233-239.

GOMM JBD and WILLIAMS JTE (1996) Development of a NeuralNetwork Predictive Controller. Liverpool John Moores University, Liverpool.

JAMES BR and BARTLETT RJ (1984) Plant-soil interaction of chromium. J. Environ. Qual. 13 (1) 67-70.

KOBYA M (2004) Removal of Cr(VI) from the aqueous solutions by adsorption onto hazelnut shell activated carbon: Kinetic and equilibrium studies. Bioresour. Technol. 91 (3) 317-321.

KURNIAWA TA, CHAN GYS, LO WH and BABEL S (2006) Physicochemical treatment technique for wastewater laden with heavy metals. Chem. Eng. J. 118 (1-2) 83-98.

LEVENSPIEL O (1999) Chemical Reaction Engineering ( $3^{\text {rd }}$ edn.). John Wiley \& Sons, New York. 668 pp.

LONGSWORTH LG (1972) Diffusion in liquids. In: Gray DW (ed.) American Institute of Physics Handbook. McGraw-Hill Book Company, New York.

MOLOKWANE PE (2010) Simulation of In Situ Bioremediation of $\mathrm{Cr}$ (VI) in Groundwater. PhD thesis, University of Pretoria, Pretoria, South Africa. URL: http://upetd.up.ac.za/thesis/available/ etd-09252010-154146/unrestricted/00front.pdf.

MOLOKWANE PE and CHIRWA EMN (2009) Microbial culture dynamics and chromium (VI) removal in packed-column microcosm reactors. Water Sci. Technol. 60 (2) 381-388.

MOLOKWANE PE, NKALAMBAYAUSI-CHIRWA EM and MELI KC (2008) Chromium (VI) reduction in activated sludge bacteria exposed to high chromium loading: Brits culture (South Africa). Water Res. 42 (17) 4538-4548.

REYNOLDS TD and RICHARDS PA (1996) Unit Operations and Processes in Environmental Engineering ( ${ }^{\text {nd }}$ edn.). PWS Publishing Company, New York.

ROSLEV P, MADSEN PL, THYME JB and HENRIKSEN K (1998) Degradation of phthalate and di-(2-ethylhexyl) phthalate by indigenous and inoculated microorganisms in sludge-amended soil. Appl. Environ. Microbiol. 64 (12) 4711-4719.

SHI WY, SHAO HB, LI H, SHAO M and DU S (2009) Progress in the remediation of hazardous heavy metal-polluted soils by natural zeolite. J. Hazardous Mater. 170 (1) 1-6.

TEKERLEKOPOULOU AG, TSIAMIS G, DERMOU E, SIOZIOUS S, BOURTZIS K and VAYENAS DV (2010) The effect of carbon source on microbial community structure and $\mathrm{Cr}(\mathrm{VI})$ reduction rate. Biotechnol. Bioeng. 107 (3) 478-487.

TSENG JK and BIELEFELDT AR (2002) Low temperature chromium(VI) biotransformation in soil with varying electron acceptors. J. Environ. Qual. 31 (6) 1831-1841.

TOWILL LE, SHRINER CR and DRURY JS (1978) Reviews of the Environmental Effects of Pollutants: Chromium. National Academy Press, Cincinnati.

TURICK CE, GRAVES C and APEL WA (1998) Bioremediation potential of $\mathrm{Cr}(\mathrm{VI})$-contaminated soil using indigenous microorganisms. Bioremed. J. 2 (1) 1-6.

WATTS RJ (1998) Hazardous Wastes: Sources, Pathways, Receptors. John Wiley \& Sons, Inc., New York. 123 pp.

WITTBRODT PR and PALMER CD (1992) Limitations to pumpand-treat remediation of a chromium contaminated site. Aquifer restoration: pump-and-treat and the alternatives. National Groundwater Association Convention, 30 September - 2 October 1992, Las Vegas.

ZABIRI H and MAZUKI N (2010) A black-box approach in modeling valve stiction. Int. J. Eng. Nat. Sci. 4 (1) 9-16.

ZAKARIA ZA, ZAKARIA Z, SURIF S and AHMAD WA (2007) Biological detoxification of $\mathrm{Cr}(\mathrm{VI})$ using wood-husk immobilized Acinetobacter haemolyticus. J. Hazardous Mater. 148 (1-2) 164-171. 